\title{
Revitalisasi RRI dan TVRI Menghadapi Pemilu 2014
}

\author{
Ahmad Budiman \\ Peneliti di Pusat Pengkajian, Pengolahan Data dan Informasi (P3DI), \\ Setjen DPR RI.
}

\begin{abstract}
Regarding to the institutional nature which is now independent and serving public interest, TVRI and RRI are very compatible to be count on in Election 2014. But there are still quite many obstacles for these institutions to handle. Revitalitation of TVRI and RRI have to be implemented immediately in the scope of facing Election 2014. Some strategic steps can be taken, include the guarantee that is resulting in more perfect and more comprehensive Bill or regulation, quality control of Election broadcasting programmes, the broadcasters' quality and quantity which are supported by creative human resources quality enhancement, and also in the matter of budget increase for those issues.
\end{abstract}

Keywords: Revitalitation of TVRI and RRI, Election 2014

\begin{abstract}
Abstrak
Dengan kondisi institusi yang kini telah mandiri dan melayani kepentingan publik, TVRI dan RRI sangatlah layak untuk diperhitungkan dalam pelaksanaan Pemilu 2014. Namun, masih terdapat beberapa hambatan dan tantangan yang harus dihadapi kedua institusi ini. Revitalisasi TVRI dan RRI harus dilaksanakan secepatnya dalam rangka menghadapi Pemilu 2014. Beberapa langkah strategi dapat diambil - termasuk jaminan dalam bentuk regulasi atau undang-undang yang lebih komprehensif dan sempurna, kontrol kualitas dalam program penyiaran mengenai Pemilu, kualitas dan kuantitas praktisi penyiaran yang didukung oleh pengembangan kualitas sumber daya kreatif, serta permasalahan keuangan.
\end{abstract}

Kata Kunci: Revitalisasi TVRI dan RRI, Pemilu 2014

\section{Pendahuluan}

Undang-Undang Nomor 32 Tahun 2002 tentang Penyiaran, pada Pasal 14 ayat (1) menyebutkan bahwa penyelenggara penyiaran publik sebagai lembaga penyiaran publik (LPP) adalah lembaga penyiaran yang berbentuk badan hukum yang didirikan oleh negara, bersifat independen, netral, tidak komersial, dan berfungsi memberikan layanan untuk kepentingan masyarakat. Selanjutnya pada ayat (2) disebutkan, "LPP terdiri atas Radio Republik Indonesia (RRI) dan Televisi Republik Indonesia (TVRI) yang stasiun pusat penyiarannya berada di ibukota Negara Republik Indonesia”.

Terkait dengan cakupan siaran, Pasal 16 Peraturan Pemerintah Nomor 11 Tahun 2005 tentang Penyelenggaraan Penyiaran Lembaga Penyiaran Publik men Pasal 16, Peraturan Pemerintah Nomor 11 Tahun 2005 tentang Penyelenggaraan 
Penyiaran Lembaga Penyiaran Publik menegaskan bahwa untuk siaran lokal RRI, TVRI, adalah cakupan wilayah layanan siaran yang meliputi wilayah di sekitar tempat kedudukan lembaga penyiaran yang bersangkutan atau wilayah satu kabupaten/kota. Cakupan wilayah siaran regional adalah cakupan wilayah layanan siaran yang meliputi wilayah satu provinsi. Selanjutnya cakupan wilayah siaran nasional adalah cakupan wilayah layanan siaran yang meliputi seluruh wilayah Negara Kesatuan Republik Indonesia (NKRI). Sedangkan cakupan wilayah siaran internasional adalah cakupan wilayah layanan siaran yang meliputi wilayah di luar wilayah NKRI.

Pada PP tersebut, khususnya pada Pasal 18 ayat (1), ayat (2) dan ayat (3) disebutkan bahwa isi siaran wajib memuat paling sedikit 60\% mata acara yang berasal dari dalam negeri. Wajib memberikan perlindungan dan pemberdayaan kepada khalayak khusus, yaitu anak-anak dan remaja, dengan menyiarkan mata acara pada waktu yang tepat dan Lembaga Penyiaran Publik dimaksud wajib mencantumkan dan/atau menyebutkan klasifikasi khalayak sesuai isi siaran. Isi siaran wajib dijaga netralitasnya dan tidak boleh mengutamakan kepentingan golongan tertentu.

Kehadiran RRI dan TVRI mempunyai karakteristik yang berbeda dengan karakteristik yang dimiliki oleh lembaga penyiaran swasta. Esensi lembaga penyiaran publik berbeda dengan lembaga penyiaran yang menganut market model yang mengutamakan economic determinism, yaitu ketika seolah-olah semua aspek tingkah laku institusi penyiaran ditentukan oleh faktor-faktor ekonomi. Lembaga penyiaran publik diharapkan mampu menjadi media intermediary yang dapat menjembatani kepentingan publik dan badan-badan publik dalam hubungannya dengan akses informasi publik secara terbuka dan transparan. Oleh sebab itu, kehadiran lembaga penyiaran publik bukan saja menjawab kebutuhan publik atas akses informasi, namun juga dapat membantu pemerintah menyediakan pasokan informasi sehingga pemerintah dapat mengambil keputusan yang tepat berdasarkan informasi yang akurat dan objektif (Ghazali, 2002: xii).

Kemampuan TVRI dan RRI sebagai lembaga penyiaran publik juga berlaku pada aktivitas Pemilu 2014 yang akan datang. Partai politik (parpol) yang telah disahkan oleh KPU sebagai parpol peserta Pemilu 2014 akan bersaing melalui kegiatan kampanye Pemilu 2014. Sedangkan UU Nomor 8 Tahun 2012 tentang Pemilihan Umum Anggota Dewan Perwakilan Rakyat, Dewan Perwakilan Daerah, dan Dewan Perwakilan Rakyat Daerah, khususnya Pasal 1 angka 29 menyebutkan, Kampanye Pemilu diartikan sebagai kegiatan Peserta Pemilu untuk meyakinkan para Pemilih dengan menawarkan visi, misi, dan program 
Peserta Pemilu. Itu artinya, keberadaan stasiun penyiaran yang berada hampir di semua provinsi menjadikan TVRI dan RRI menjadi media penyiaran yang efektif untuk melakukan sosialisasi terhadap visi dan misi parpol serta caleg untuk dapat diterima oleh seluruh masyarakat di wilayahnya.

TVRI dan RRI dalam konteks Pemilu tidak sama dengan lembaga penyiaran swasta yang masih dihadapkan kepada persoalan kepemilikan yang terpusat pada beberapa orang pemilik modal. Pemusatan kepemilikan ini berpotensi menggiring adanya pembentukan opini publik. Bukan hanya kepemilikan lembaga penyiaran yang terpusat pada segelintir orang saja, akan tetapi kepemilikan lembaga penyiaran ini juga terlihat ada kecenderungan keberpihakan kepada parpol tertentu. Monopoli dan juga persaingan yang tidak sehat pada media media penyiaran dapat terjadi dan dapat mengganggu pelaksanaan Pemilu 2014.

TVRI dan RRI memiliki potensi yang strategis dalam meningkatkan kualitas pelaksanaan pemilu sekaligus meningkatkan partisipasi masyarakat dalam kegiatan pemilu. Kedudukan yang strategis sebagai media sosialisasi Pemilu 2014 ini disebabkan oleh sifat lembaga penyiaran yang: a) independen, neteral, adil dan berimbang; b) menyampaikan aspirasi dan informasi public; c) menyajikan program-program yang bersifat informatif dan edukatif; d) memiliki kontrol sosial terhadap penyelenggaraan Pemilu yang Langsung Umum Bebas Rahasia Jujur dan Adil (Luber dan Jurdil); e) melaksanakan agenda setting nasional dan daerah, agar kebijakan redaksional baik siaran dan pemberitaan tidak melenceng dari prinsip penyiaran publik serta ketentuan KPI mengenai P3SPS.

Pada praktiknya, keberadaan UU No. 32 Tahun 2002 tentang Penyiaran dan Peraturan perundangan lainnya masih belum memberikan ruang dan kepastian hukum yang jelas dengan keberadaan TVRI dan RRI sebagai lembaga penyiaran publik. Pembentukan badan hukum LPP yang didirikan oleh negara menjadi tidak jelas keberadaannya dan status badan hukumnya. Hal ini yang kemudian menyebabkan TVRI dan RRI banyak menghadapi kendala dalam mengoptimalkan kinerjanya, terutama terkait dengan ketersediaan anggaran, eksistensi dan kompetensi sumber daya manusia (SDM), pengelolaan dan pemeliharaan alat peralatan siaran dan pemancar serta aset yang dimiliki lainnya, dan yang lebih penting adalah antisipasi pemindahan teknologi digitalisasi pada penyiaran publik.

Permasalahan berikutnya terkait dengan kemampuan jangkauan siaran dari TVRI dan RRI. Sebagai lembaga penyiaran publik yang harus menjangkau masyarakat di seluruh wilayah NKRI, pada tahun 2012 ini TVRI hanya mampu meng-cover $68 \%$ dari seluruh 
area/wilayah RI, sedangkan untuk jangkauan siarannya dengan coverage population hanya mencapai $40 \%$ dari seluruh penduduk RI. Sedangkan RRI hingga saat ini memiliki 80 stasiun penyiaran untuk meng-cover di seluruh wilayah NKRI. Selain itu RRI memiliki 13 studio produksi baik berada di perbatasan antar negara maupun daerah blankspot.

Pada pelaksanaannya, kondisi ini sangat dipengaruhi oleh kendala yang timbul dari pemancarluasan isi siaran. Kendala terkait dengan pemancarluasan isi siaran di antaranya sarana dan prasarana penyiaran khususnya untuk stasiun penyiaran di daerah baik jumlah maupun usianya sudah tua dengan kemampuan yang sangat terbatas. Kondisi pemancar juga sudah sangat tua dan mengalami penurunan kemampuan untuk memancarkan isi siaran, sementara suku cadangnya yang sudah sulit dicari. Sejalan dengan perkembangan waktu, akan banyak dijumpai daerah yang tidak terjangkau isi siaran TVRI dan RRI (Laporan Kinerja TVRI dan RRI tahun 2012).

Dalam satu tahun terakhir, TVRI dan RRI telah berupaya meningkatkan kualitas dan kuantitas program meskipun masih tertinggal dari lembaga penyiaran swasta khususnya menghadapi Pemilu Tahun 2014. Memang tidak bisa dipungkiri, materi dan kemasan program siaran TVRI dan RRI kualitasnya masih jauh dari apa yang diharapkan oleh masyarakat. Kendala keterbatasan anggaran dan dukungan peralatan serta kualitas SDM kreatif, menyebabkan kebijakan program siaran membagi rata antara program produksi terbaru dan program daur ulang (Budiman, Laporan Penelitian: 2012). Kendala ini tentunya memiliki pengaruh juga pada kemampuan menghasilkan program siaran menarik yang khusus membahas masalah Pemilu 2014 sesuai dengan kebutuhan masyarakat.

Permasalahan sumber daya manusia (SDM) juga memberikan kontribusi yang signifikan terhadap pengembangan kinerja RRI dan TVRI. RRI digerakkan oleh 5.364 PNS dan 1.528 Pegawai Bukan PNS (PBPNS) sehingga total SDM yang mengelolanya berjumlah 6.892 orang. Hingga saat ini, rekrutmen SDM kreatif baru sebagai pengganti SDM lama jarang dilakukan, padahal prosentase usia SDM terbanyak berada pada rentang usia 51-55 tahun atau 42,12\% dari seluruh jumlah SDM yang ada. Kelompok berikutnya berada pada kategori umur 46-50 tahun sebesar 37,1\%. Kedua pengelompokkan ini termasuk pada kategori usia yang kemampuan produktivitasnya sudah tidak lagi optimal. Kondisi seperti ini juga hampir sama terjadi pada SDM TVRI (Laporan Kinerja TVRI dan RRI tahun 2012). 
Publik dan Lembaga Penyiaran Publik

Secara khusus, publik dalam istilah penyiaran publik diposisikan sekaligus dalam dua pengertian yakni sebagai khalayak (pemirsa atau pendengar) dan sebagai partisipan yang aktif. Pemahaman ini terkait dengan kebebasan menyatakan pendapat, hak untuk mendapatkan informasi, serta upaya pemberdayaan masyarakat dalam proses menuju masyarakat madani. Selanjutnya Eric Barendt membuat definisi tentang media penyiaran publik (public service broadcasting) sebagai media yang: 1) tersedia (available) secara generalgeografis; 2) memiliki concern terhadap identitas dan kultur nasional; 3) bersifat independen, baik dari kepentingan negara maupun kepentingan komersil; 4) memiliki imparsialitas program; 5) memiliki ragam varietas program; dan 6) pembiayaannya dibebankan kepada pengguna media.

Definisi tersebut mengandaikan bahwa penyiaran publik dibangun didasarkan pada kepentingan, aspirasi, serta gagasan publik yang dibuat berdasarkan swadaya dan swamandiri dari masyarakat atau publik pengguna dan pemetik manfaat penyiaran publik. Lembaga penyiaran publik juga memfasilitasi pembentukan opini publik dengan menempatkan dirinya sebagai wadah independen untuk perdebatan publik, menyangkut isu ekonomi, politik, sosial, dan budaya (Ghazali, 2002: 15-18).
Fungsi sosial media penyiaran publik yang cukup signifikan menurut Lasswell yaitu:

1. Pengawas sosial (social surveillance), merujuk pada upaya penyebaran informasi dan interpretasi yang objektif mengenai berbagai peristiwa yang terjadi di dalam dan di luar lingkungan sosial. Tujuannya adalah sebagai kontrol sosial agar tidak terjadi hal-hal yang tidak diinginkan.

2. Korelasi sosial (social correlation), merujuk pada upaya pemberian interpretasi dan informasi yang menghubungkan satu kelompok sosial dengan kelompok sosial yang lainnya atau antara satu pandangan dengan pandangan lainnya, dengan tujuan mencari konsensus.

3. Sosialisasi (Socialization), merujuk pada upaya pewarisan nilai-nilai dari satu generasi ke generasi lainnya, atau dari satu kelompok ke kelompok lainnya (dalam Mufid, 2007: 80).

Urgensi penyiaran publik menurut Dennis McQuail sebagaimana dikutip Mufid (2007) adalah untuk menjunjung nilai-nilai yang banyak ditinggalkan oleh media komersial, seperti independensi, solidaritas, keanekaragaman (opini dan akses), objektivitas, dan kualitas informasi. Secara filosofis, urgensi kehadiran media penyiaran publik berangkat dari kehidupan publik yang dilihat dari posisi sebagai warga masyarakat hanya dalam dua ranah, yaitu 
dalam lingkup kekuasaan dan lingkup pasar. Pandangan dikotomis ini mengabaikan kenyataan lainnya, yaitu adanya ranah publik (public sphere) yang diharapkan dapat menjadi zona bebas dan netral. Idealnya, di dalamnya berlangsung dinamika kehidupan yang bersih dari kekuasaan dan pasar.

Mengingat peranannya yang vital, penataan media dianggap tak bisa diserahkan kepada mekanisme pasar. Media yang sehat bukanlah media yang memperoleh untung besar, melainkan media yang dapat menyajikan informasi bernilai penting bagi publik. Media massa juga diharapkan dapat menyajikan beragam informasi yang dapat memberdayakan publik untuk berpartisipasi aktif dalam demokrasi. Konsekuensinya, negara harus menjaga agar keberagaman kepemilikan media dapat dipelihara. Kalau semua diserahkan kepada mekanisme pasar, ada kekhawatiran bahwa ada banyak informasi yang sebenarnya dibutuhkan masyarakat, tetapi tidak disajikan media hanya karena tak cukup atraktif sebagai komoditas (Armando, 2011: 5).

Nilai kultural ini merupakan pemaknaan atas setiap kegiatan dalam ranah publik. Ini dapat dilihat dengan dua cara. Pertama, secara negatif, yaitu dominasi dan monopoli kekuasaan dan pasar harus dijauhkan dari kehidupan publik. Kedua, secara positif, yaitu membangun otonomi dan independensi institusi sosial. Mesti terbuka peluang untuk membangun format baru atas keberadaan media penyiaran publik menjadi institusi otonom dan independen yang menjalankan fungsi kultural dalam ranah publik (Mufid, 2007: 81).

Pada negara otoriter, lembaga penyiaran yang dimiliki oleh pemerintah menjadi alat pemerintah dan bersifat propagandis. Lembaga penyiaran publik di negara demokrasi adalah lembaga penyiaran yang independen, didirikan oleh negara untuk kepentingan publik, bukan alat propaganda pemerintah. Misalnya di Amerika Serikat, lembaga penyiaran publik yang mereka sebut dengan public broadcasting dananya didukung oleh masyarakat dan negara. Hal itu terjadi karena masyarakat tidak puas dengan hanya memiliki lembaga penyiaran swasta yang sangat komersial yang sering kali melupakan fungsi pendidikan dan kepentingan publik lainnya (Siregar, 2009).

Fungsi utama stasiun publik di Indonesia adalah memberikan layanan kepada masyarakat. Hal ini merupakan faktor pertama yang harus dipertimbangkan sebelum menyusun strategi program. Pada dasarnya, apa saja bisa dijadikan program untuk ditayangkan di televisi selama program itu menarik dan disukai audiens, dan selama tidak bertentangan dengan kesusilaan, hukum dan peraturan yang berlaku (Morissan, 2010: 208). 


\section{Revitalisasi TVRI dan RRI}

\section{Urgensi RUU RTRI}

RUU Usul Inisiatif DPR RI tentang Penyiaran mengatur bahwa pasal mengenai Lembaga Penyiaran Publik diamanatkan untuk dibentuk menjadi Radio Televisi Republik Indonesia (RTRI) yang ketentuan lebih lanjut mengenai RTRI akan diatur dengan undang-undang. Adapun aturan tersebut bertujuan untuk memberikan penguatan kepada LPP sebagai lembaga negara yang berfungsi untuk memberikan informasi yang berimbang kepada masyarakat.

Pembentukan lembaga negara mandiri di Indonesia merupakan hal yang diharapkan dapat memberikan penyelesaian permasalahan di Indonesia. Pembentukan lembaga mandiri ini bertujuan membantu pemerintah dalam melaksanakan tugas dan tanggung jawabnya, yaitu melindungi bangsa dan juga mencerdaskan kehidupan masyarakat melalui kegiatan penyiaran. Pembentukan lembaga mandiri ini juga berorientasi kepada kepentingan masyarakat. LPP sebagai lembaga penyiaran yang dimiliki oleh publik harus memiliki kemandirian yang tidak dapat diinterfensi oleh pihak manapun. Kemandirian dari LPP merupakan hal yang mutlak, hal ini dikarenakan LPP merupakan bagian dari masyarakat yang dimiliki oleh masyarakat dan keberadaannya untuk masyarakat.

Peranan RTRI dirasakan sangat penting bagi bangsa Indonesia, yakni sebagai salah satu media informasi dan juga sebagai alat pemersatu bangsa. Dapat dikatakan bahwa RTRI dipandang sebagai jembatan penghubung antar berbagai kalangan. Sebagai lembaga penyiaran publik, RTRI dapat dilihat sebagai upaya mempertahankan jati diri ranah penyiaran, sebagai ruang simbolik kultural di tengah tren komersialisasi dan komodifikasi. RTRI bertujuan untuk menjalin persatuan dan kesatuan bangsa, melestarikan dan mengembangkan nilainilai, budaya, dan jati diri bangsa, memberikan kontribusi pada pembangunan demokrasi, mengembangkan masyarakat yang informatif, meningkatkan kesejahteraan masyarakat, serta meningkatkan citra dan daya saing bangsa.

Pengajuan RUU usul inisiatif Komisi I DPR RI tentang RTRI sebagai RUU yang diajukan di luar Prolegnas terdiri dari naskah akademik dan draft RUU RTRI yang terdiri atas 11 bab dan 68 pasal yang mengatur mengenai ketentuan umum, tujuan dan ruang lingkup, fungsi tugas dan kegiatan, kedudukan, sistem penyiaran, kelembagaan, pembiayaan dan pertanggungjawaban, aset, penyelenggaraan siaran, standar siaran, isi siaran dan bahasa siaran, penyiaran publik dengan teknologi digital, ketentuan peralihan, dan ketentuan penutup.

Kehadiran RUU tentang RTRI diharapkan menjadi landasan normatif bagi pengaturan mengenai Lembaga RTRI sebagai Lembaga Penyiaran Publik dalam 
rangka meningkatkan kinerjanya serta mengatasi sejumlah kendala seperti pengelolaan organisasi, pengembangan SDM (termasuk juga SDM kreatif), sumber pembiayaan, program siaran, dan pemancarluasan isi siaran, optimalisasi penyiaran publik di daerah perbatasan, serta antisipasi perkembangan teknologi penyiaran digital.

Pasal 23 ayat (2) UU No. 12 Tahun 2011 mengatur tentang Pembentukan Peraturan Perundang-undangan berkaitan dengan keadaan tertentu lainnya yang memastikan adanya urgensi nasional atas suatu RUU yang dapat disetujui bersama oleh alat kelengkapan DPR yang khusus menangani bidang legislasi dan menteri yang menyelenggarakan urusan pemerintahan di bidang hukum. Karena it, diharapkan RUU tentang Radio Televisi Republik Indonesia (RTRI) ini dapat masuk dalam Prolegnas daftar kumulatif terbuka pada tahun 2013, sehingga dapat segera dibahas bersama dengan Pemerintah.

\section{Percepatan Revitalisasi LPP TVRI dan LPP RRI}

Pada posisinya sebagai lembaga penyiaran publik, TVRI dan RRI memiliki kekuatan untuk mengatasi berbagai hambatan yang pada umumnya terjadi pada media massa. TVRI dan RRI memiliki kemampuan untuk mengatasi hambatan psikologis, hambatan sosiokultural, dan hambatan interaksi verbal (Ardianto dan Erdimaya, 2007: 83). Selain dari posisinya, maka dari sifatnya yang independen TVRI dan RRI memiliki kesempatan besar untuk mengatasi hambatan psikologis yang meliputi hambatan kepentingan (interest). Kepentingan akan membuat masyarakat selektif dalam menanggapi atau menghayati pesan. Masalah ini dapat dijawab oleh keanekaragaman program yang sesuai dengan kebutuhan masyarakat.

TVRI dan RRI secara filosofis memiliki kekuatan dalam menyerukan suara hati nurani (calls for inner voice), menyerukan musyawarah untuk mencapai mufakat (calls for deliberation to reach a consensus), menyerukan kebebasan dalam kendali kearifan (calls for freedom with wisdom driven), menyerukan merawat peradaban bangsa (calls for caring human civilization), dan menyerukan peningkatan derajat kemuliaan umat manusia (calls for dignifying the ultimate noble of human being).

TVRI dan RRI sebagai LPP melalui program siarannya dapat berfungsi sebagai alat identitas nasional (Flag Carrier) dan alat integrasi bangsa. Sebab, penyiaran publik mempunyai kekuatan menghimpun kesatuan sosial, mengikat kelompok-kelompok, wilayah-wilayah, maupun kelas-kelas dalam keberagaman melalui siaran-siaran langsung atau peristiwa-peristiwa nasional. Program siaran TVRI dan RRI yang berada dalam masyarakat multikultur seperti di 
Indonesia harus memberikan upaya pada kontribusi "nation building" dan memberikan hak masyarakat untuk mengetahui informasi yang benar (right to know) dan hak masyarakat untuk mengemukakan pendapat serta mengekspresikan diri (right to expression).

Sifat lembaga TVRI dan RRI yang independen memiliki pengaruh yang sangat signifikan terhadap program acara yang disajikan, termasuk juga program acara Pemilu. Program acara Pemilu 2014 yang disajikan TVRI dan RRI dapat bersifat independen dan memberikan kesempatan yang sama terhadap semua parpol dan para calon legislatif (caleg) untuk menggunakannya. Hal ini menyebabkannya mampu mengatasi hambatan prasangka (prejudice) yang berkaitan dengan persepsi orang tentang seseorang atau kelompok lain dan sikap serta perilakunya terhadap mereka.

Memberikan kesempatan yang sama kepada semua parpol dan caleg, akan menjadikan program acara Pemilu 2014 yang diusung terbebas dari hambatan stereotipe. Stereotipe adalah gambaran atau tanggapan tertentu mengenai sifat-sifat dan watak pribadi orang atau golongan lain yang bercorak negatif. Terakhir, visi dan misi yang jelas sebagai media pemersatu bangsa, maka program acara Pemilu ini akan dapat meningkatkan pengetahuan, memengaruhi sikap masyarakat terhadap Pemilu, dan memotivasi masyarakat untuk menggunakan hak pilihnya. Netralitas lembaga dan program acara yang disajikan akan mampu meyakinkan masyarakat terhadap kegiatan Pemilu yang sedang terlaksana. Hal ini tentunya sejalan dengan prinsip komunikasi yang menyebutkan, semakin sesuai pesan komunikasi dengan motivasi seseorang maka semakin besar kemungkinan komunikasi itu dapat diterima dengan baik oleh komunikan.

Program acara Pemilu yang disajikan TVRI dan RRI akan jauh berbeda dengan apa yang disajikan lembaga penyiaran swasta. TVRI dan RRI dengan jaminan UU tidak akan terjebak pada konflik kepentingan pada media terkait dua pihak yakni penguasa dan pengusaha. Program acara TVRI dan RRI dilarang menjadi alat kekuatan sosialpolitik. Seluruh materi siaran tidak harus dikonfirmaskan terlebih dahulu dengan berbagai pemegang kepentingan politik. Pelayanan TVRI dan RRI sesuai dengan kebutuhan masyarakat dan bukan untuk kepentingan politis. Kondisi ini menyebabkan program acara Pemilu 2014 di TVRI dan RRI lebih mampu memenuhi dan menciptakan selera publiknya.

Mewujudkan TVRI dan RRI sebagai media Pemilu 2014 milik negara melalui program acara pemilu yang berkualitas, memang sangat perlu ditunjang oleh kesiapan sumber daya manusia (SDM) yang handal. Memang hingga kini kedua lembaga penyiaran publik ini tidak dapat melakukan 
rekrutmen pegawai. Untuk itu langkah strategis perlu dilakukan yaitu dengan melakukan dan mengawasi pelaksanaan reformasi birokrasi di TVRI dan RRI. Pada tingkat lokal, perlu direkrut tenaga ahli bidang IT, desainer grafis, pembawa acara, reporter, dan profesi lain. Mereka akan bekerja sebagai SDM kreatif sesuai dengan ketentuan peraturan perundangundangan yang berlaku. Selain itu, untuk meningkatkan motivasi kerja perlu ditingkatkan kesejahteraan karyawan melalui peningkatan tunjangan. Terakhir, perlu dilakukan pendidikan dan pelatihan profesi baik di dalam maupun di luar negeri untuk meningkatkan keahlian dan keterampilan teknis, kompetensi, kapabilitas dan kapasitas SDM di bidang produksi acara, penyiaran, dan profesiprofesi lainnya yang terkait dengan penyiaran.

Kebijakan pemancarluasan isi siaran yang dilakukan TVRI dan RRI memang berbeda dengan yang dilakukan oleh LPS. Kebanyakan LPS hanya mau memancarluaskan ke daerah-daerah yang menguntungkan dan target audiens yang dipentingkan adalah pembeli program. Hal ini berbeda dengan yang dilakukan TVRI dan RRI yang pemancarluasan isi siaran perlu disesuaikan dengan luasnya sebaran penduduk, mulai wilayah perkotaan sampai ke daerah pelosok, daerah pegunungan yang jauh, bahkan pulau-pulau kecil dan daerah terpencil lainya. Sedangkan penduduk di wilayah terpencil, tetap perlu mendapat pelayanan siaran televisi seperti halnya masyarakat perkotaan.

Rencana menjadikan TVRI dan RRI sebagai media Pemilu 2014 juga perlu ditunjang dengan upaya untuk mengatasi kendala penyebarluasan isi siaran. Revitalisasi perlu dilakukan melalui pembaharuan infrastruktur teknis LPP TVRI dan LPP RRI berupa pemancar, menara pemancar, peralatan studio, dan peralatan produksi yang masih minim dan usang. Kemudian secara bertahap dilakukan penggantian pemancar di seluruh wilayah Indonesia dari pemancar dengan menggunakan sistem analog menuju pemancar dengan sistem digital. Selain itu perlu juga dilakukan peningkatan kualitas pemancar di seluruh stasiun daerah perbatasan.

Peningkatan kualitas pemancar memang sangat dipengaruhi oleh kekuatan anggaran yang tersedia. Becermin dari penyerapan anggaran tahun 2012 di TVRI dari pagu anggaran sebesar Rp. 758.807.880.000,- mencapai sebesar 94,5\% atau Rp. 717.070.898.087,--. Sedangkan di RRI pada tahun 2012 alokasi anggaran sebesar Rp. 769.437.633.0oo,- terealisir sebanyak Rp. 676.477.614.755,- atau sebesar 87,97\%. Selanjutnya pada tahun 2013, pagu anggaran RRI meningkat menjadi Rp. 985.177.413.000,- dan pagu anggaran TVRI meningkat menjadi Rp. 864.207.104.000,-. Untuk menjalankan misinya sebagai media pemilu, maka perlu dilakukan usulan perubahan anggaran 
baik TVRI dan RRI melalui APBN Perubahan tahun 2013 yang prioritas peruntukannya adalah pada peningkatan kualitas pemancar dan program siaran.

Untuk mewujudkan percepatan revitalisasi RRI dan TVRI menghadapi Pemilu 2014, maka sistematika rencana strategis yang perlu mendapatkan perhatian adalah:

a) Jaminan perlindungan hukum kelembagaan RRI dan TVRI perlu segera disahkan. Jaminan ini akan menjadi panduan bagi kedua lembaga ini untuk mengoptimalkan kinerjanya sebagai lembaga penyiaran publik yang independen, netral dan tidak komersil, jaringannya luas dengan misi utama adalah membangun karakter dan citra bangsa.

b) Menjadikan panduan hukum dimaksud sebagai perintah untuk menghasilkan rencana strategis (renstra) sebagai turunannya.

c) Pada tataran operasional, perlu dilakukan penguatan kelembagaan, sumber dana, SDM (termasuk SDM kreatif) dan perlindungan jaminan hukum atas aset-aset yang dimiliki.

d) Peningkatan kualitas konten/program siaran termasuk dalam waktu dekat meningkatkan kualitas program siaran yang terkait dengan pelaksanaan Pemilu 2014.

e) Perluasan koneksitas jaringan. f) Menggantian seluruh alat peralatan penyiaran dan pemancar dengan mengalihkannya kepada teknologi penyiaran digital.

g) Memperluas pemangku kepentingan dan jumlah pemirsa/pendengar agar mampu bersaing dengan jumlah pemirsa pada program acara yang ditayangkan LPS.

\section{Penutup}

TVRI dan RRI memiliki potensi yang besar dalam mengemban amanat sebagai media Pemilu 2014 nantinya. Namun demikian program acara yang disajikan bukan berarti program siaran yang "pas-pasan”. Kemasan program acara radio dan televisi publik yang diolah secara profesional, bisa memikat masyarakat dan bersaing dengan paket acara LPS, walapun sasaran akhir kedua lembaga penyiaran ini jelas berbeda. LPS memang ditujukan sebagai lahan bisnis mencari untung, sedang LPP dimaksudkan untuk melayani kebutuhan publik dalam informasi, pencerahan dan pencerdasan. Namun "persaingan" ini adalah juga ancaman bagi kelangsungan kedua LPP ini untuk tetap diakui oleh masyarakat.

Pengembangan kemampuan untuk menghasilkan program siaran yang berkualitas adalah sebuah keharusan yang tidak bisa dibantah lagi. Tidak tepat bila merasa "aman" karena karakter penyiaran 
publik dan penyiaran swasta adalah berbeda dalam merebut perhatian masyarakat pendengar/pemirsanya. Identifikasi acara untuk penyiaran publik sudah banyak dikreasikan menjadi program acara di LPS dan hasilnya berpotensi menarik perhatian masyarakat. Karena itu, penataan program siaran penyiaran publik harus dilakukan berdasarkan hasil evaluasi terhadap program yang selama ini telah dan akan berjalan.

Untuk itu, RUU tentang RTRI harus didorong sebagai sebuah keharusan dalam rangka memberikan jaminan perlindungan hukum terhadap upaya revitalisasi kelembagaan penyiaran publik, pengembangan SDM (termasuk juga SDM kreatif), sumber pembiayaan, program siaran, dan pemancarluasan isi siaran, optimalisasi penyiaran publik di daerah perbatasan, serta antisipasi perkembangan teknologi penyiaran digital.

Hal lain terkait dengan peningkatkan kualitas program siaran dengan berpegang teguh pada prinsip penyiaran publik dan terutama dalam kaitannya sebagai media Pemilu 2014 yang disertai dengan penambahan anggaran penyiaran publik terutama menghadapi kegiatan Pemilu 2014. Peningkatan kualitas SDM TVRI dan RRI dapat dilakukan dengan menekankan kepada keberadaan SDM kreatif agar dapat meningkatkan kualitas kinerja lembaga penyiaran publik dan menjadikan
TVRI dan RRI sebagai lembaga penyiaran publik yang dibutuhkan oleh masyarakat.

\section{Daftar Pustaka}

Ardianto, Elvinaro dan Erdimaya, Lukita Komala. 2007. Komunikasi Massa Suatu Pengantar. Bandung: Simbiosa Rekatama Media.

Armando, Ade. 2011. Televisi Jakarta di Atas Indonesia. Bandung: Bentang Pustaka.

Budiman, Ahmad. 2012. Laporan Penelitian Individu Penataan Program Siaran dan Pemancaluasan Isi Siaran, P3DI Setjen DPR RI.

Ghazali, Effendi. 2002. Penyiaran Alternatif tapi Mutlak, Sebuah Acuan tentang Penyiaran Publik dan Komunitas. Jakarta: Jurusan Ilmu Komunikasi FISIP UI.

Laporan Kinerja TVRI Tahun 2012 dan Perencanaan Kinerja Tahun 2013. Rapat kerja Komisi I DPR RI Januari 2013.

Morissan. 2010. Jurnalistik Televisi Mutakhir. Jakarta: Penerbit Kencana Media Group.

Mufid, Muhamad. 2007. Komunikasi dan Regulasi Penyiaran. Jakarta: UIN Press. 
Peraturan Pemerintah Nomor 11 Tahun 2005 tentang Penyelenggaraan Penyiaran Lembaga Penyiaran Publik.

Siregar, Amir Effendi. "Memberdayakan TVRI”, Media Indonesia. Jumat, 28 Agustus 2009.
Undang-Undang Nomor 32 Tahun 2002 tentang Penyiaran.

Undang-Undang Nomor 8 Tahun 2012 tentang Pemilihan Umum Anggota Dewan Perwakilan Rakyat, Dewan Perwakilan Daerah, dan Dewan Perwakilan Rakyat Daerah. 
Jurnal komunikasi, Volume 7, Nomor 2, April 2013 